\title{
NR1I2 wt Allele
}

National Cancer Institute

\section{Source}

National Cancer Institute. NR112 wt Allele. NCI Thesaurus. Code C127843.

Human NR1/2 wild-type allele is located within 3q12-q13.3 and is approximately $38 \mathrm{~kb}$ in length. This allele, which encodes nuclear receptor subfamily 1 group I member 2 protein, plays a role in the regulation of both gene expression and steroid metabolism. 